\title{
Plant Exploration: From Queen Hatshepsut to Sir Joseph Banks
}

\author{
Jules Janick \\ Department of Horticulture and Landscape Architecture, 625 Agriculture Mall Drive, \\ Purdue University, West Lafayette, IN 47907-2010
}

Additional index words. Fruit genetic resources, germplasm

\begin{abstract}
The worldwide exchange of fruits has been facilitated by traders, travelers, sovereigns, conquerors, diplomats, missionaries, and botanists. The beginnings of organized plant exploration date to the Pharaohs of ancient Egypt, who, as early as 2000 вСе, brought back exotic trees and plants in their foreign campaigns and illustrated them on their temple walls. Queen Hatshepsut (са. 1500 все) sent out ships to bring back trees from the land of Punt (northeast African coast). The exchange of plants throughout antiquity was a by-product of trade routes between East and West as well as though the campaigns of conquerors including Alexander, the warriors of Islam, Genghis Khan, and the crusades. The age of exploration starting at the end of the 15th century was inspired by the search for a sea route to the spice-rich East. The encounter of Columbus with the Americas brought about an explosive exchange of New World and Old World plants. The rise of science in the 17th and 18th centuries was associated with botanical exploration involving travels and expeditions, including Hans Sloan to the West Indies, James Cunningham to China, Georg Eberhard Rumpf (Rumphius) to the Moluccas, and Sir Joseph Banks to Newfoundland, Labrador, South America Tahiti, New Zealand, Australia, the Malay Archipelago, Hebrides, and Iceland.
\end{abstract}

The quest for new crop plants and domestic animals is a recurrent theme in human history. The discovery of agriculture replaced the collection of products of indigenous plant and animal species with the cultivation of crops and rearing of domestic animals. This led naturally to the search, discovery, and introduction of new crops from travel, trade, warfare, and conquest. The discovery and exploitation of new crops as a dividend of conquest might be distinct from direct exploration to find new useful species, but often these two methods become intertwined. This brief review emphasizing fruit crops will discuss the exploration and discovery of useful plants from antiquity to the 18th century largely from a Western perspective.

\section{ANTIQUITY}

Mesopotamia. The ancient development of fruit culture in Mesopotamia derives from archeological remains of fruit, from pictorial images, and literary evidence. The Sumerian discovery of writing in the third millennium BCE provides a literary tradition that includes fruit crops. One of the earliest evidence of crop diversity includes the illustrations on the Uruk vase (Fig. 1), late fourth millennium, showing a wedding ceremony, probably between a priest king and goddess, perhaps Innana, later known as Istar (Pollock, 1999). The imagery from the bottom to the top of the vase depicts water, suggesting irrigation, followed by plants (barley and sesame), domestic animals, and nude attendants bearing baskets of fruit as offerings (Bahrani, 2002). Unfortunately, the fruits cannot be identified,

\footnotetext{
The cost of publishing this paper was defrayed in part by the payment of page charges. Under postal regulations, this paper therefore must be hereby marked advertisement solely to indicate this fact. Email: janick@purdue.edu.
}

but they seem large and suggest that the cultivation of fruits had long been established.

Horticulture, agriculture, and fruit cultivation in the following 3000 years are well represented in the collection of sacred writings of the Hebrew Bible, Christian Bible, and the Koran-the bases of Judaism, Christianity, and Islam - with abundant references to fruit and fruit growing, particularly grapes, dates, olives, and pomegranates (Goor and Nurock, 1968). The various books of these sacred texts cover 2000 years of history and include mention of a great many plants. Some are Asian imports, such as the spices cinnamon and cassia, indicating the trade between East and West. Reference to this ancient trade is found in the Hebrew Bible (Genesis 37:25): Abraham leaves the Sumerian city of Ur to dwell in Canaan (ca. 2000 BCE). His favorite son Joseph is cast in a ditch by his jealous brothers, when they decide against fratricide: "And they lifted up their eyes and looked, and, behold, a company of Ishmaelites came from Gilead with their camels bearing spicery and balm, and myrrh, going to carry it down to Egypt." The brothers sell Joseph to the spice merchants for 20 pieces of silver.

Ancient Egypt. Some of the non-indigenous crops of ancient Egypt date to Neolithic and predynastic periods (Darby et al., 1977; Janick, 2002). The origin of these crops (wheat, barley, dates) became embedded in the bewildering theology developed by the ancient Egyptians and was incorporated in legends and art. Thus, papyrus, the symbol of Lower Egypt, and the lotus, the symbol of Upper Egypt, were incorporated in numerous paintings of hunting scenes and floral offerings, as well as the architectural designs of columns. The unification of Upper and Lower Egypt is expressed not only by the fused hats of the pharaohs but also by the ceremonial intertwining of these two plants (Fig. 2). The time frame for introduction of new fruits in Egypt can be determined from a combination of literary and archeological evidence (Table 1).

The development of Egyptian agriculture did not occur in a vacuum. Egypt was an aggressive culture, and at one time Egypt ruled from present-day Libya in the West, to Syria in the northeast, and Ethiopia and Somalia and perhaps portions of Sub-Saharan Africa in the south. Egypt continuously incorporated technology as well as new crops from the Fertile Crescent (present-day Israel, Jordan, Lebanon, Syria, and Iraq) as well as Africa. In addition, there were contacts with the world beyond, including Southern and Western Africa, Western Asia, and even China. Strands of silk have been found on mummies of the Pharaohs, dating to about $1000 \mathrm{BCE}$, indicating an ancient exchange of spices and fabrics from caravan routes and water routes. Streams of immigrants and captives, as well as invasions by others-such as the Persians in 525 BCE and the Greeks and Romans (332-30 BCE) contribute to new introductions of germplasm and technology.

The first evidence of direct exploration for new plant resources is in $2500 \mathrm{BCE}$, when the Pharaoh Sankhere sent a fleet down the Red Sea to search for supplies of prepared spices. Interest in new plants is underscored when the Egyptian scribe Sinuhe describes $Y a a$, the name for present-day Israel: "It was a goodly land called Yaa. Figs were in it and grapes, and its wine was more abundant than water. Plentiful was its honey, many were its olives; all manner of fruits were upon its trees" (Goor and Nurock, 1968). The first recorded expedition for obtaining living plants was that of the famous Queen Hatshepsut to the land of Punt, Northeastern Coast of Africa, to fetch the fabulous biblical resins frankincense (Boswellia) and myrrh (Commiphora). An image of the expedition preserved in a temple at "Deir elBahri," ca. 1500 BCE, shows two ships being loaded with living plants (Fig. 3). Later, in 1450 BCE, the queen's nephew Thothmes III 

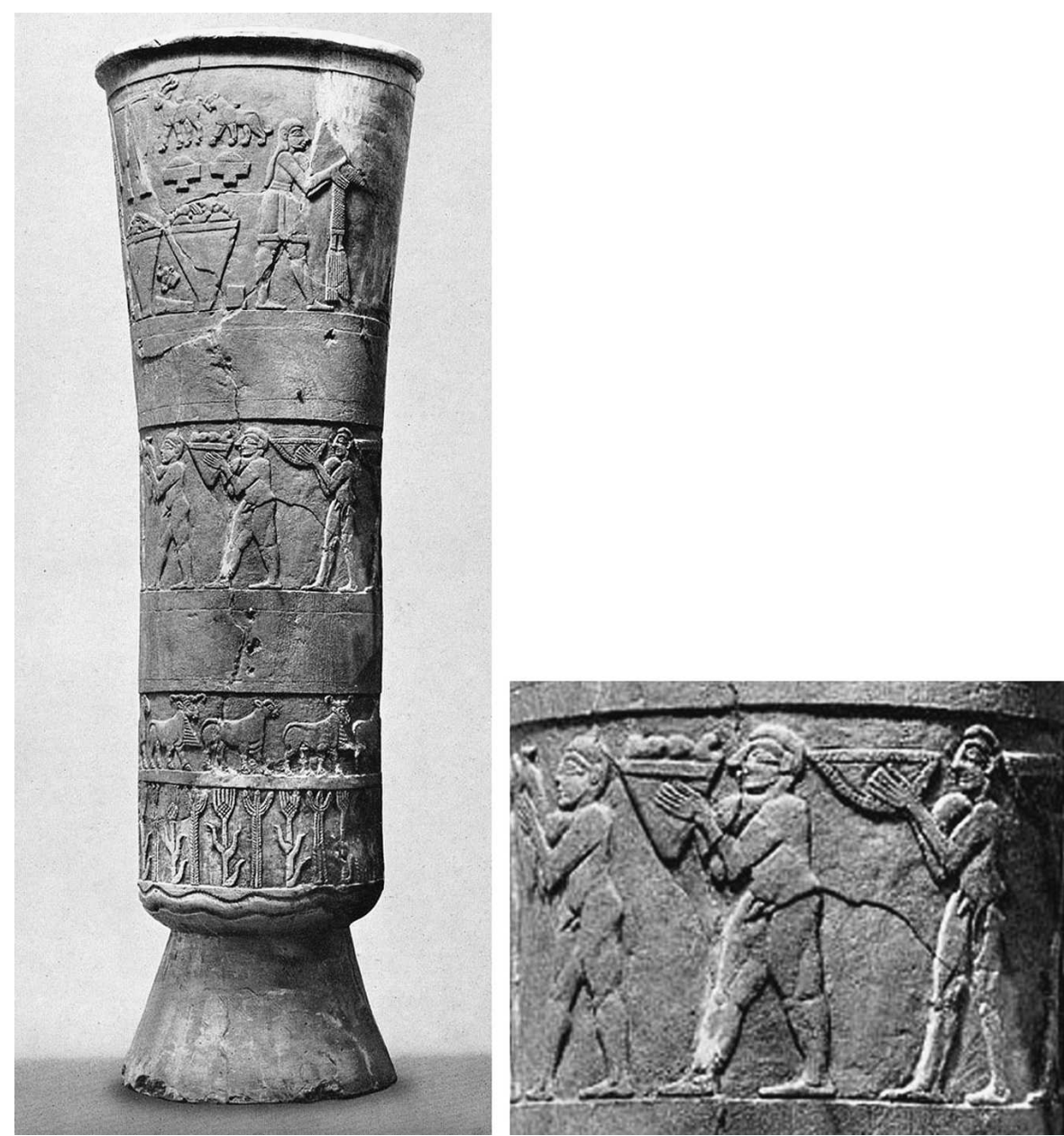

Fig. 1. Uruk vase (3500-3000 вСE).
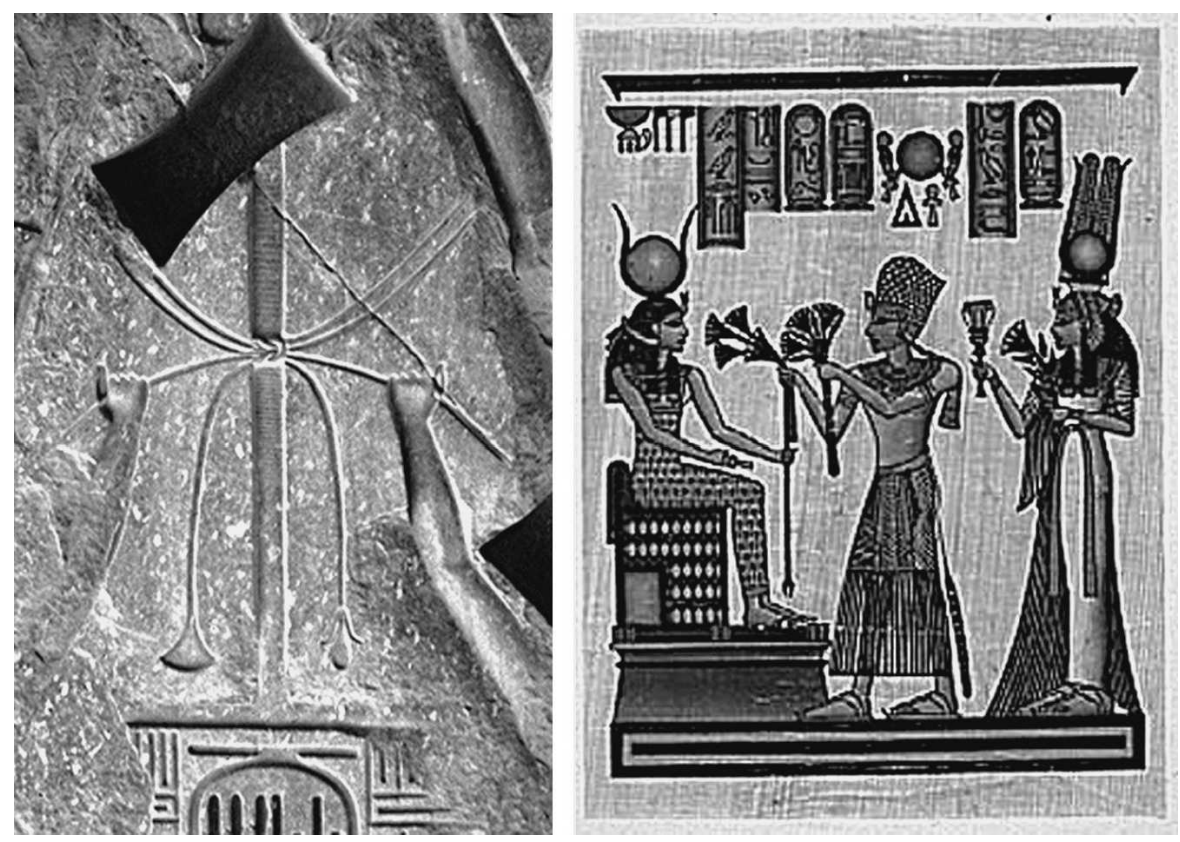

Fig. 2. Papyrus and lotus: symbols of Upper and Lower Egypt.

had strange plants and seeds from Syria carved on the Temple of Karnak (Singer et al., 1954; Janick, 2002). Ramses III (1198-1166) is credited with making great vineyards, walks shaded by all kinds of sweet fruit trees, a sacred way splendid with flowers from all countries, with lotus and papyrus as numerous as the sand (Huxley, 1978).

\section{GREECE}

The writings of Hippocrates (460?-359? $\mathrm{BCE})$, the Father of Medicine, are filled with plant lore. He was the first to note the influence of food and diet on health. Writings of his school (Pseudo-Hippocrates) contain the first written evidence of grafting (Meyer, 1854) through a description of the graft union, an important technique for the introduction of new fruit species.

The plant writings of Aristotle (384323 BCE) are lost, but two volumes written by his pupil Theophrastus (371-287? BCE) entitled The History of Plants and The Causes of Plants have been preserved (Janick, 1989). These are the earliest botanical works to have survived, and they deal with 500-550 species, many from distant locations, such as the banana. Theophrastus had many disciples (students who probably supplied information and plant specimens).

Alexander the Great (356-323 BCE), son of Philip of Macedonia and student of Aristotle, had a profound influence on the introduction of west Asian plants to Europe (Parry, 1969). Alexander conquered Persia, Turkistan, Afghanistan, Pakistan, and northwest India, including the Indus Valley. Greek settlements and commercial posts were founded between the Mediterranean and India along the western section of trade routes, which became known as the Silk Road (Fig. 4) Alexander's campaign led to increased botanical knowledge concerning herbs and spices, and the cities that he established became the western routes for many Asian fruits. With the conquest of Egypt, the new city of Alexandria became the most important trading center between the Mediterranean and Indian Ocean, and was known as the Gateway to the East.

\section{MIDDLE AGES}

The great movement of crop plants in the Middle Ages was facilitated by Muslim conquests in the first century after the death of the prophet Mohammed in 632. Islam, the new religion, spread rapidly to Egypt and almost all of the North Africa, up the Iberian Peninsula into France, incursions in the Mediterranean including Sicily and southern Italy, moving east through the Byzantine empire through Western India up to the gates of China, and extending to southeast Asia. The defeat of the Byzantine empire permitted the ancient lore of plants to be translated from Greek to Arabic, and the Arabs in the first century clearly were more advanced than the Europeans, especially in science (mathematics and astronomy) and agriculture (Reed, 1942). Their literature held a number of botanical works. Avicenna [Ibn Sina (980-1037)], a Persian by birth, was a student of botany whose Canon of Medicine was encyclopedic and translated into Latin. Averroes [Ibn Roschid (11251198)], a native of Cordoba who became the greatest nature philosopher of the Middle Ages, compiled a great work on Islamic 
Table 1. Evidence for fruit crops in Egypt. ${ }^{\mathrm{z}}$

\begin{tabular}{lllc}
\hline Common name & \multicolumn{1}{c}{ Scientific name } & \multicolumn{1}{c}{$\begin{array}{c}\text { Earliest record } \\
\text { (dynasty or period) }\end{array}$} & Type of evidence \\
\hline Date palm & Phoenix dactylifera & Pre-dynastic & Archeological \\
Doum palm & Hyphaene thebaica & Pre-dynastic & Archeological \\
Sycamore fig & Ficus sycomorus & Pre-dynastic & Archeological \\
Jujube (Christ's thorn) & Ziziphus spina-christi & I (Old Kingdom) & Archeological \\
Fig & Ficus carica & II (Old Kingdom) & Artistic \\
Grape & Vitis vinifera & II (Old Kingdom) & Archeological \\
Hegelig & Balanites aegyptiaca & III (Old Kingdom) & Archeological \\
Persea (lebakh) & Mimusops shimperi & III (Old Kingdom) & Archeological \\
Argun palm & Medemia argun & V (Old Kingdom) & Archeological \\
Carob & Ceratonia siliqua & XII (Middle Kingdom) & Archeological \\
Pomegranate & Punica granata & XII (Middle Kingdom) & Archeological \\
Egyptian plum & Cordia myxa & XVIII (New Kingdom) & Archeological \\
$\quad$ (sehestem, mokheit) & & & \\
Olive & Olea europea & XVIII (New Kingdom) & Archeological \\
Apple & Malus $\times$ domestica & XVIII (New Kingdom) & Literary \\
Peach & Prunus persica & Graeco-Roman & Archeological \\
Pear & Pyrus communis & Graeco-Roman & Archeological \\
Cherry & Prunus avium; & 5 BCE & Literary \\
Citron & P. cerasus & & Second century CE \\
\hline Source: Aitrus medica & & Literary \\
\hline
\end{tabular}

${ }^{\mathrm{z}}$ Source: Adapted from Darby et al. (1977).

${ }^{y}$ A questionable literary reference dates to the first dynasty.

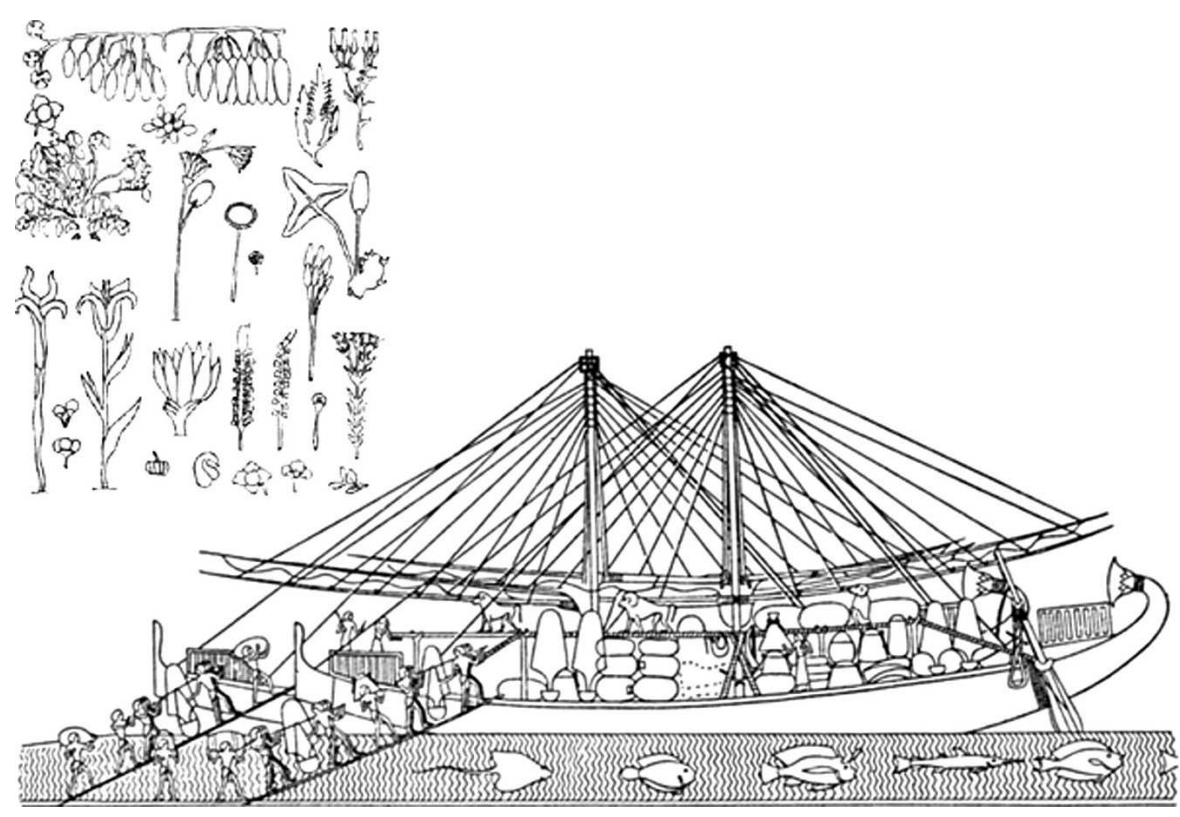

Fig. 3. Ships of Queen Hatshepsut's fleet landing at Punt with exotic merchandise for Egypt. Deir el-Bahri (ca. 1500 BCE). Inset: Plants brought back from Syria by Thothmes II and carved on the temple of Karnak (ca. 1450 BCE).

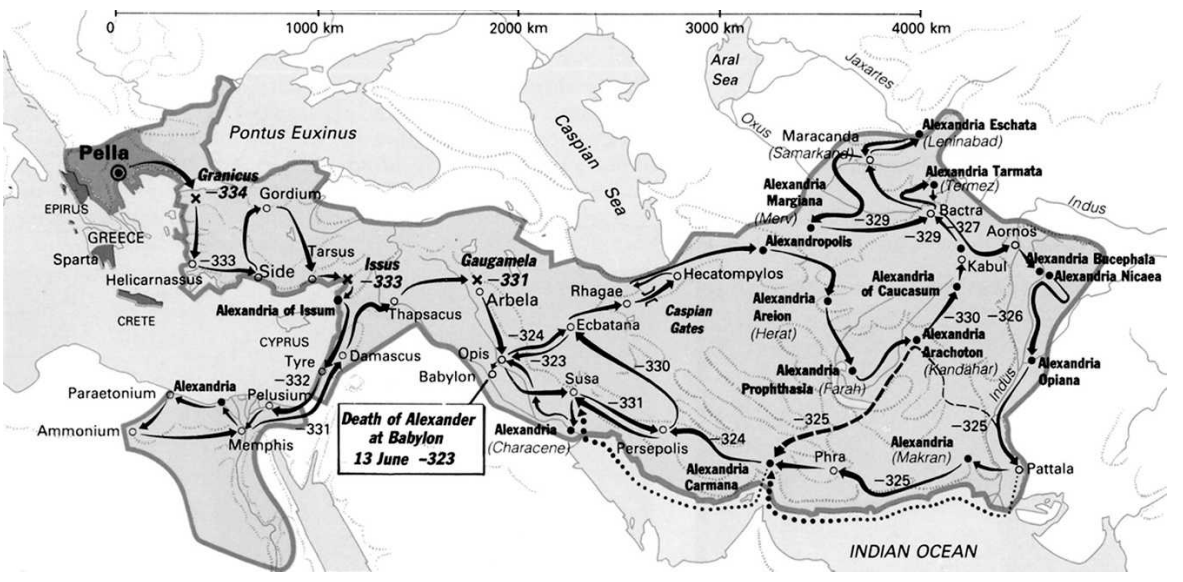

Fig. 4. Empire of Alexander the Great (323 вСE). botany. Ibn Baithar, born in Malaga, died in 1248 , in Damascus, traveled in search of plants in Tunis, Egypt, Greece, Syria, and as far as Medina and Mosul, and, from personal observation, described over 1400 plants. His book on lemons was published in Latin in 1583 and 1602.

The technology of producing refined crystalline sugar from sugarcane was but one example of the exchange of crops and technology that was spread to Europe via the Arabs. Agricultural technology and new crops via the Arabs reached the rest of Europe after the incursions of the West into Jerusalem (the crusades) and from the reconquest of the Iberian Peninsula by Christian warriors.

At the same time, the aggressive mounted tribes of Central Asia (deprecated as barbarians by the Greeks), consisting of Turks, Mongols, and Tibetans, became a dominant power as they moved east and west, eventually conquering vast areas of the GrecoRoman World. Unstable empires of the steppes eventually reunited under Temujin (ca. 1155 to 1227), who took the name Genghis Khan in 1206 (Fig. 5). The "Conqueror of the World" formed a Mongol empire that stretched from the Pacific to the Black Sea, from Northern China to the Siberian Taiga, the Volga Plain and Persia, and marched to the gates of Vienna before being halted in 1241. Mongol invasion into India was a decisive turning point in the subcontinent. The Mongol Empire opened the way for a host of European visitors, missionaries, and traders to journey throughout Eurasia. The Mogul gardens still remain in India, indicating the influence of this culture on horticulture.

\section{AGE OF EXPLORATION}

The quest of the West for a route to the spice-rich East (Janick, 2003a) was spurred on by reports of medieval travelers, such as Marco Polo (Fig. 6). It was intensified by the steady stream of Eastern goods to the West through Constantinople, which was controlled by the enterprising merchants of Venice, who were the masters of the trade in the Adriatic. The quest became reality

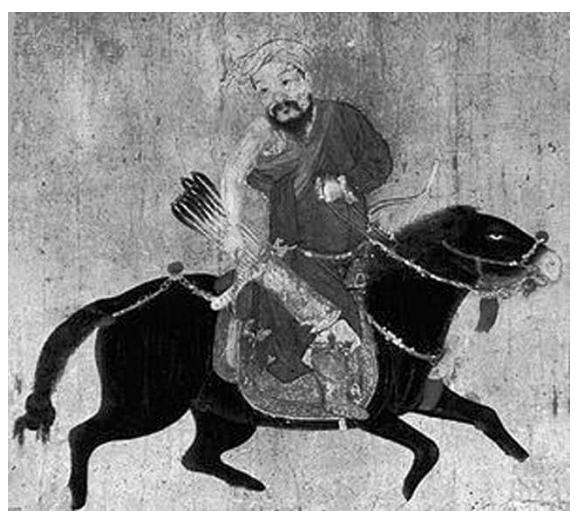

Fig. 5. Genghis Khan (1155-1227). 


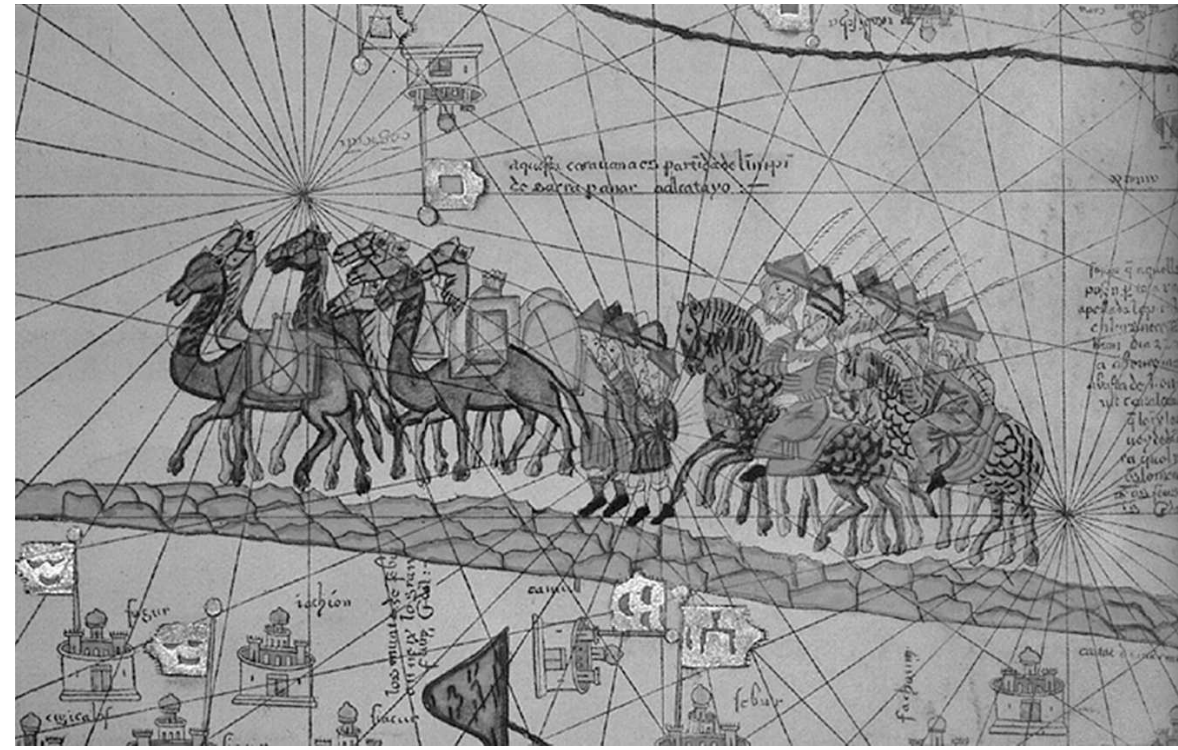

Fig. 6. Marco Polo (1254-1324).

through the daring journeys of Portuguese navigators and seamen to India and China and by Spanish conquistadores to the New World.

Somewhat earlier, in the beginning of the 15 th century, treasure ships of China explored Southeast Asia, India, and Africa, even bringing back giraffes to China (Fig. 7). If we are to accept the conjectures of Gavin Menzies, a British Royal Navy Submarine Commanding Officer, the Chinese fleet under the Admiral Zheng He (a Moslem eunuch!) sailed between 1421 and 1423, reached the Americas, circumnavigated the globe, discovered Australia and New Zealand, exchanged plants, and sailed close to the North Pole (Menzies, 2003).

Christopher Columbus. The encounter between Christopher Columbus (Fig. 8) and the Americas was directly responsible for the mass transfer of New and Old World species that was to have a profound effect on agriculture. In his journal, Columbus wrote (Parry, 1969):

We ran along the coast of the island, westward from the islet and found its length to be 12 leagues as far as a cape which I named Cabo Hermoso [Cape Beautiful], at the western end. The island is beautiful,...I believe that there are many herbs and many trees that are worth much in Europe for dyes and for medicines; but I do no know them, and this causes me great sorrow.

There are trees of a thousand sorts, and all have their several fruits; and I feel the most unhappy man in the world not to know them, for I am well assured they are valuable.

I desired to set out today for the island of Cuba, which I think must be Cipangu, according to the signs these people make, indicative of its size and riches,...It is better to go where there is great entertainment, so I say that it is not reasonable to wait, but rather to continue the voyage and inspect much land, until some very profitable country is reached, my belief being that it will be rich in spices. That I have no knowledge of these products causes me the greatest sorrow in the world, for
I see a thousand kinds of trees, each one with it own special fruits, as well as a thousand kinds of herbs with their flowers; yet I known none of them...

In his second voyage, he discovered allspice (Pimenta racemosa or officinalis).

We found there a tree whose leaf had the finest smell of cloves that I ever met with; it was the laurel leave, but not so large: I think it is a species of laurel.

Columbus returned to Spain from the first voyage in Apr. 1493, via Lisbon and brought back cotton. He encountered maize, based on letters written in 1493 (later collected and published as De Orbo Novo in 1511) from Peter Martyr D'Anghera, an Italian teacher to the Spanish court, to Ascanio Sforza, Cardinal Vice Chancellor of the Vatican (MacNutt, 1912). Columbus' second voyage was sent out in Dec. 1493 involving 17 ships carrying between 1200 and 1500 people. Plants carried to the New World included wheat, barley, grapevine cuttings, chickpea, melons, olives, fruit stones for planting, onions, lettuce, and radishes (Deagan and Cruxent, 2002). At the Canary Islands, more provisions, including sugarcane, were resupplied. Some ships laden with materials from the New World returned in 1494, although Columbus did not return for 6 more years. A May 1494 letter from Peter Martyr D'Anghera to Cardinal Sforza referred to a package of seeds "of all kinds," including maize. The transfer of crops between the New and Old Worlds was extremely rapid with enormous implications for the history of the world.

Vasco da Gama. In 1497, the Portuguese explorer Vasco de Gama (Fig. 9) sailed around the Cape of Good Hope to Mozambique and then directly from India to Calcutta, the fabled city of spices and emporium of cinnamon, ginger, and black pepper. The days of Venetian control of spices into Europe comes to an end, and the enrichment of Portugal begins.

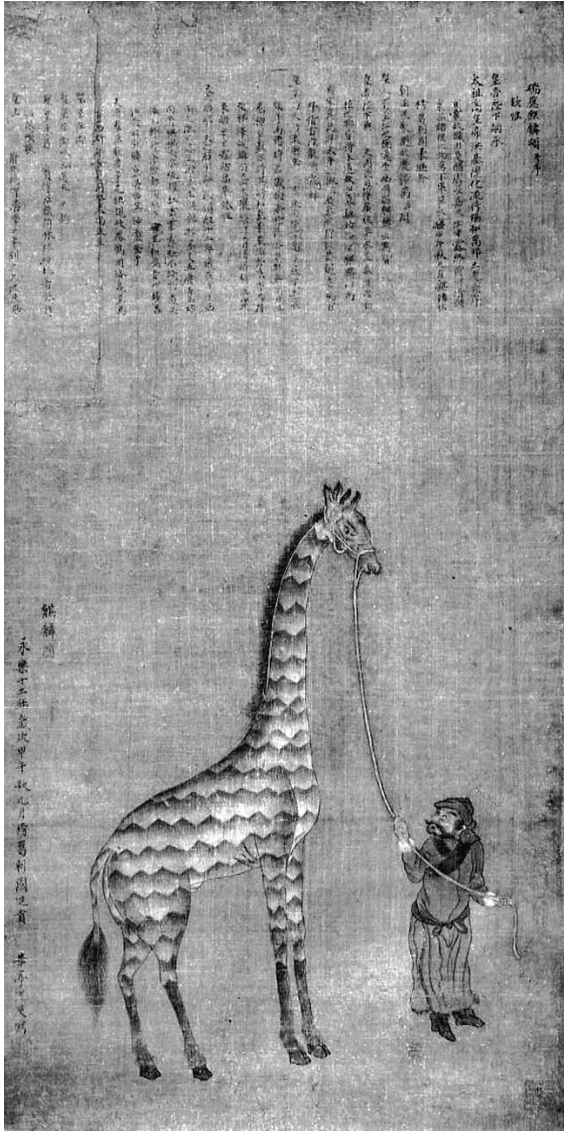

Fig. 7. Giraffe sent to Ming Imperial Court as a tribute (1414).

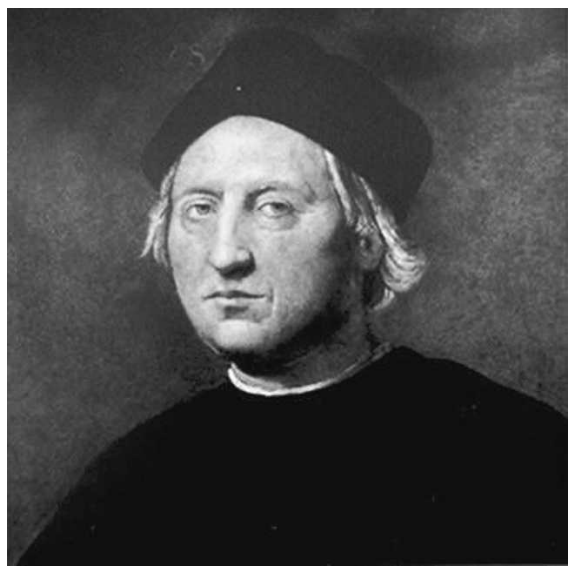

Fig. 8. Christopher Columbus (1451-1506).

Ferdinand Magellan. Circumnavigation of the world (1519-1522) by the ships of the Portuguese explorer, Ferdinand Magellan (Fig. 10) was indirectly responsible for the introduction of New World plants in China. Sailing under the Spanish flag under a commission by Charles V of Spain, Magellan discovers the straits that today bear his name and claims the Philippines for Spain. However, he perishes there in a battle against the island king of Cebu, in an attempt to subjugate the neighboring island of Matan. Magellan's fleet discovered the western route to the Spice Islands, and one of the three 


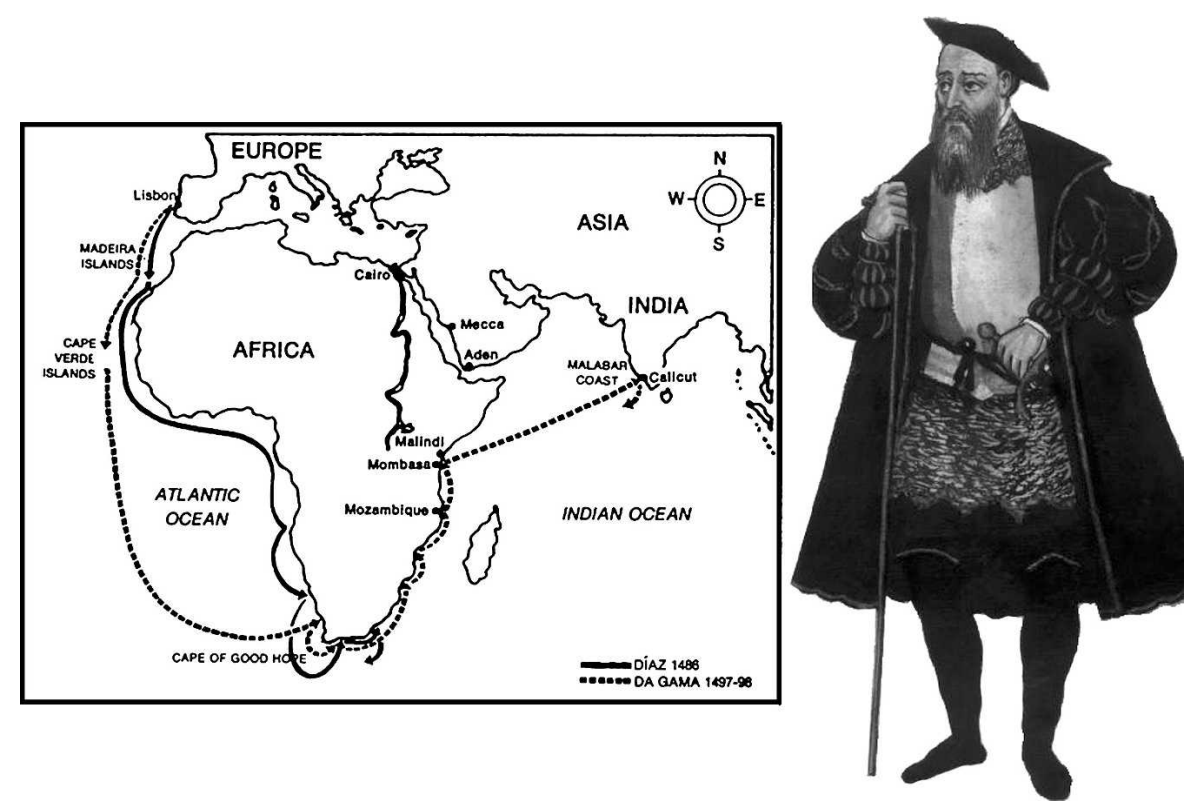

Fig. 9. Vasco da Gama (1469-1525) and his voyage of 1497 reaching Calicut, India.

ships, Victoria, returned to Spain led by Sebastian del Cano. New World crops including tobacco and various crops prefixed in Chinese by the word fan (southern barbarian or foreign devil) enter China through Manila, including tomato (fan eggplant), guava (fan pomegranate), papaya (fan quince), dicama, and yam bean (fan kudzu) become important parts of Chinese agriculture. Peanut is first mentioned about 1538 , maize in 1555 , and sweetpotato by 1594, known under the Aztec name camotl or by Chinese names such as calle chin-shu (golden tuber), pai-shu (white tuber), or fan-shu (barbarian tuber), or kan-shu (sweet tuber).

\section{AGE OF SCIENCE}

Herbals. Written descriptions of plants with their properties and medicinal virtues (termed herbals in the 16th century) were

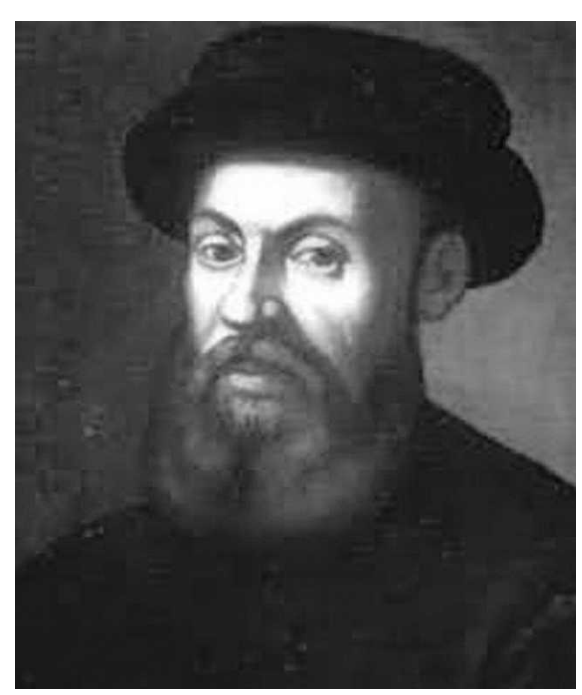

Fig. 10. Ferdinand Magellan (1470-1591). long sourcebooks for physicians and apothecaries, but they also contain much information about the spread of new plants (Janick, 2003b). The earliest medicobotanical treatises date to antiquity. A Sumerian tablet from about 2100 BCE contains a dozen prescriptions, many involving plant medicines (Fig. 11). The Ebers Papyrus, a medical treatise from ancient Egypt, dates to 1550 BCE but contains material from 3 to 20 centuries earlier (Fig. 12). In Greece, the great botanical treatises of Theophrastus devoted one book to the medicinal value of herbs. The first century herbal, De Material Medica, by Pedanious Discoirides of Anazarba, a Roman army physician, was slavishly referred to, copied, and commented on for 1500 years. At the same time in China, the Pen T'Sao Ching containing about 100 herbal recipes was compiled and ascribed to the legendary emperor Shen Nung of 2700 BCE. The great epoch of printed herbals appears in the 16th century, stimulated by the rise of learning and the discovery and exploration of plants in the New World and Far East. Notable works include Herbarum Vivae Eicones (1520, 1532, 1536) by Otto Brunfel; Kreviter Buch (1542) by Heironymus Bock (Tragus); De Historias Stirpium (1542) by Leonhart Fuchs; New Herball (1551, 1562, 1568 ) by William Turner; Commentarii "on Dioscorides" (1544) by Pier Andrea Mattioli; Crộ̈deboeck (1554) of Rembert Dodoens; Histoire des Plantes (1557) by Charles de L'Escluse (L'Ecluse); Stirpium Adversaria Nova by Matthias de L'Obel; and the Herball (1597) by John Gerard. Explorations of the 18th century resulted in beautiful florilegiums and stunningly illustrated botanical works (Fig. 3).

17th and 18th Century Plant Exploration. Botanical plant collecting was a major scientific activity in the 17 th and 18 th centuries (Reed, 1942). John Tradescant, Royal Gardener in England, made considerable

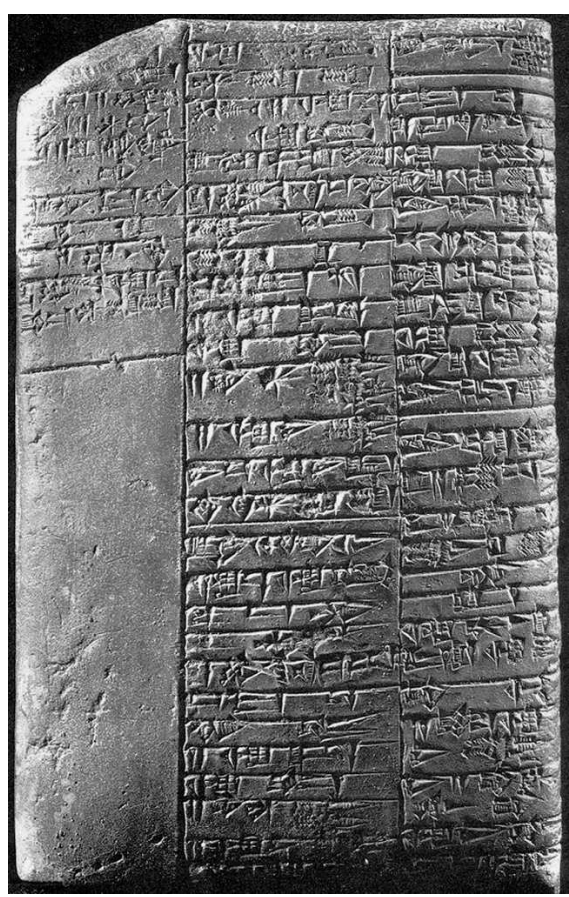

Fig. 11. A Sumerian cuneiform tablet $(\approx 2100 \mathrm{BCE})$ is the earliest known medical text.

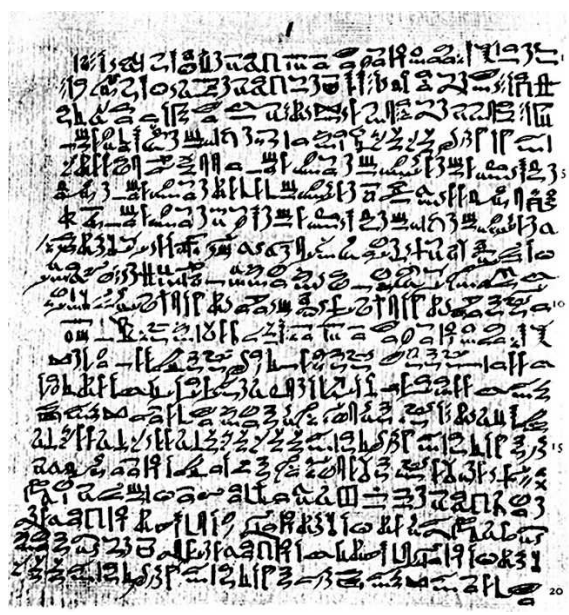

Fig. 12. The Ebers Papyrus in Hieratic script (1530 BCE).

collections in natural history and is presumed to have journeyed to Russia in 1618 for plants. In 1620, he joined an expedition against the pirates of Algiers, bringing back a variety of apricots. William Boe, a native of the Netherlands, collected in Spain and Portugal (1608), Tunis, and Barbary, returning with seeds of 200 plants. Carolus Linnaeus (1707-1778), the great taxonomist who developed the binomial system of nomenclature, sent out collectors to discover new plants that would fill in the gaps in his system of classification (an arbitrary system based on number of stamens in the flower). Other botanical explorers include Hans Sloane (1660-1753), who embarked on a trip to the West Indies as physician to the Duke of Albermarle, brought back 800 species of 
plants in 1689, and published Catalogus Plantarum (1696). James Cunningham was sent to China in 1698, and he has the distinction of being the first European to make botanical collections. $\mathrm{He}$ is the first English writer to provide an accurate description of the tea tree. Georg Eberhard Rumph, known as Rumphius (1628-1702), an employee of the Dutch East India Company, authored an enormous work on the natural history of Amboina, an island southwest of Ceram. His work Herbarium Amoinense (1741-1755) contains descriptions and illustrations of 1700 entries (many varieties). Although fire destroyed some of his manuscripts and the first six books were lost in a sea battle, his work survived through a manuscript copy and was reconstructed.

Joseph Banks. The Englishman, Joseph Banks (1743-1820), intrepid botanist and plant collector of the late 18th century (O'Brian, 1987), was president of the Royal Society for 42 years starting in 1778. Independently wealthy, Banks became justly famous as a plant collector as a young man (Fig. 13). His first scientific collecting trip was to Newfoundland and Labrador, from which he brought back information on 340 plants; for this feat he was elected as a Fellow of the Royal Society. Shortly thereafter, at the age of 25, he jointed Captain Cook on his trip around the world on the Endeavor, visiting Madeira (bringing back 700 specimens!), Rio de Janeiro, Cape Horn, Tahiti, New Zealand, Australia (vast collections in southeastern Australia provided the name Botany Bay), the Malay Archipelago, Cape of Good Hope, and St. Helena. Cook's collections include 100 new genera and 1300 new species. On his return, he received an honorary doctorate from Oxford, the university he had left degreeless a few years earlier.

Banks backed out of the next trip with Cook because he deemed the accommodations insufficient (he wanted space for 12 assistants) and had doubts about the seaworthiness of the ship. In 1772, he explored the Hebrides and Iceland, the last of his personal explorations. At the conclusion of this journey, he was made scientific advisor to Kew Gardens, then a Royal Estate, by King George III. He had the somewhat dubious distinction for developing the penal colony in Australia. In 1787, he started his campaign to deliver the breadfruit tree to the West Indies under William Bligh in the infamous HMS Bounty. Banks was knighted in 1791 and became an administrator of science through his contacts as president of the Royal Society. In 1804, he was one of a group to found the Royal Horticultural Society. A wealthy man, he leveraged his fortune to send other botanists
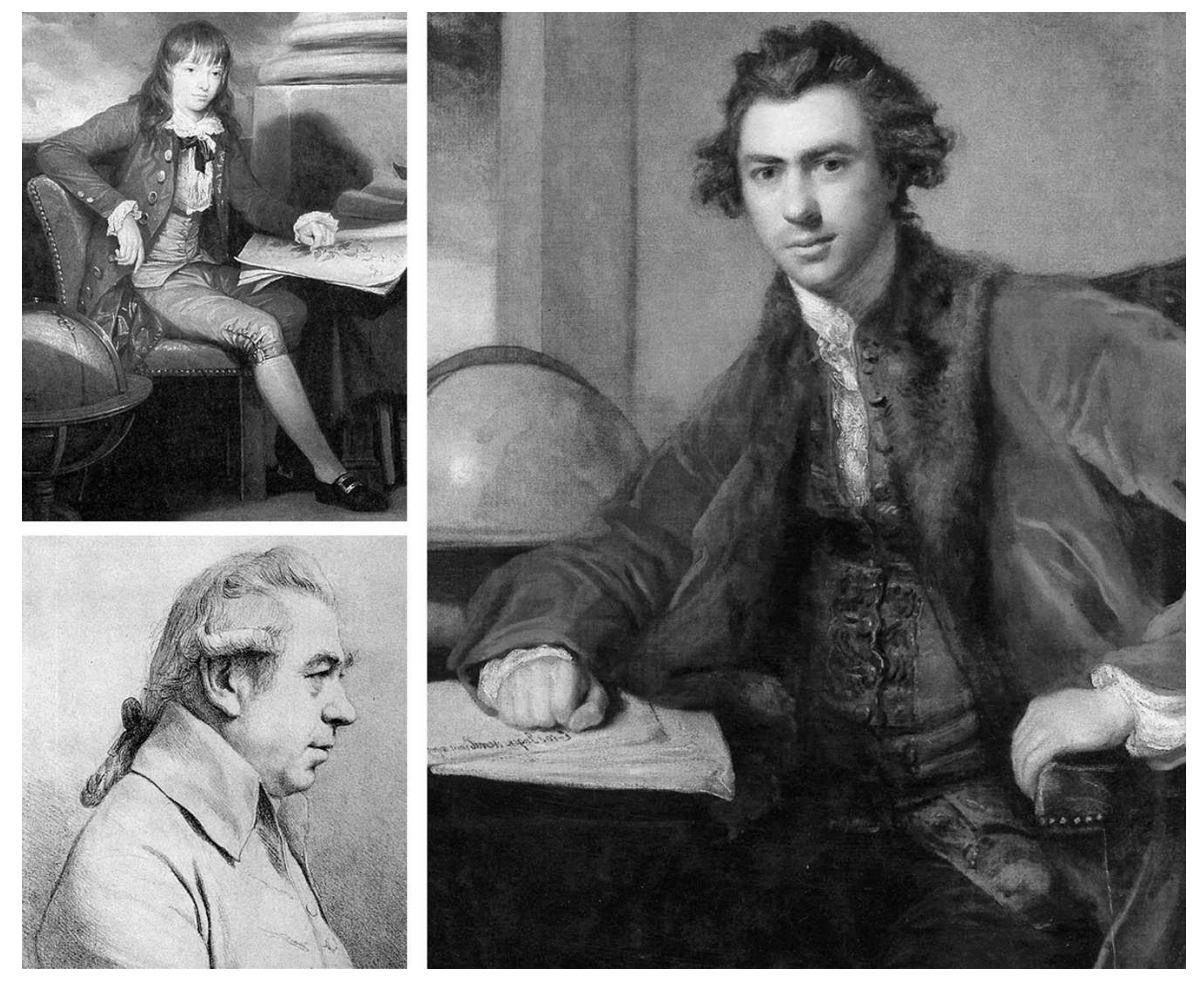

Fig. 13. Sir Joseph Banks (1743-1820).

on plant expeditions: James Bowie and Francis Masson to the Cape of Good Hope; Mungo Park to Africa and the East Indies; Allan Cunningham and George Sutter to South America; Anton Howe to India; and David Burton, George Caley, Robert Brown, Alan Cunningham, and George Sutter to Australia. Banks should be considered the first modern promoter of plant expeditions.

\section{Literature Cited}

Bahrani, Z. 2002. Performativity and the image: narrative, representation, and the Uruk vase, p. 15-22. In: E. Ehrenberg (ed.). Leaving no stones unturned: Essays on the ancient Near East and Egypt in honor of Donald P. Hansen. Eisenbrauns, Winona Lake, Ind.

Darby, W.J., P. Ghaliongui, and L. Grivetti. 1977. Food: The gift of Osiris. 2 vol. Academic Press, San Diego, Calif.

Deagan, K. and J.M. Cruxent. 2002. Columbus's outpost among the Tainos: Spain and America at La Isabela, 1493-1498. Yale Univ. Press, New Haven, Conn.

Goor, A. and M. Nurock. 1968. The fruits of the holy land. Israel Univ. Press, Jerusalem.

Huxley, A. 1978. An illustrated history of gardening. Paddington Press, New York.

Janick, J. 1989. Theophrastus, p. 3-5. In: Classical papers in horticultural science. Prentice Hall, Englewood Cliffs, N.J.
Janick, J. 2002. Ancient Egyptian agriculture and the origins of horticulture. Acta Hort. 582: 23-39.

Janick, J. 2003a. History of Asian horticultural technology. Acta Hort. 620:19-32.

Janick, J. 2003b. Herbals: the connection between horticulture and medicine. HortTechnology 13:229-238.

MacNutt, F.A. 1912. (translator). De orbe novo: The eight decades of Peter Martyr D'Anghera. http://www.guttenberg.net/1/2/4/2/12425/ 12425-h/12425-h.htm.

Menzies, G. 2003. 1421: The year China discovered America. Harper Collins, New York.

Meyer, E.H.F. 1854. Geschichte der Botanik: Studien. Verlag der Gebrüder Bornträger, Königsberg.

O’Brian, P. 1987. Joseph Banks: A life. Collins Harvill, London.

Parry, J.W. 1969. Spices: the story of spices; the spices described. 2 vol. Chem. Publ. Co., New York.

Pollock, S. 1999. Ancient Mesopotamia: The Eden that never was. Cambridge Univ. Press, Cambridge, U.K.

Reed, H.S. 1942. A short history of the plant sciences. Chronica Botanica Do., T. 1988. The plant hunters. PAJ Publications, New York.

Singer, C., E.H. Holmyard, and A.R. Fall. 1954. A history of technology. Vol. 1. From early times to ancient empires. Oxford Univ. Press, London. 